\title{
ANNOUNCEMENTS
}

\author{
Call For Abstracts \\ American Quaternary Association Seventh Biennial Meeting
}

University of Washington, Seattle, Washington

June $28-30,1982$

Pre- and Post-Conference Field Trips

June 26-27, July $1-2$

Conference Theme: "Character and Timing of Rapid Environmental and Climatic Changes."

Abstract forms and Instructions will be mailed out to members in November along with preliminary details of program and field trip options. Deadline for Abstracts is January 15, 1982.

\section{U.S. National Committee for INQUA Announces Travel Support Program for XI INQUA Congress in USSR}

The U.S. National Committee of the International Union for Quaternary Research (INQUA) is seeking funding for a travel support program to ensure that the United States will be represented by an adequate number of qualified scientists at the XI International Congress of INQUA, to meet in Moscow, USSR, August 1-9, 1982. Funds for this purpose, now being solicited from a number of government agencies and private institutions, will be coordinated by the U.S. National Committee for INQUA. Applications from younger scientists are encouraged.

Applicants for travel grant support should request application forms from $\mathrm{Mr}$. W. L. Petrie, USNC/INQUA, National Academy of Sciences, 2101 Constitution Ave., N.W., Washington, D.C. 20418. Four completed application forms, together with four copies of the abstract of the paper submitted to INQUA, must be received by the Academy Office no later than January 15, 1982. Grant awards may be made as late as July 15,1982 , depending on funds received. If possible, some advance indication of tentative selections will be communicated earlier.

The purpose of the International Union for Quaternary Research (INQUA) is to bring together on a worldwide basis scientists in all disciplines concerned with the history of man's environment, and with the processes by which environment and man's relation to it have evolved. Included among these disciplines are: archaeology, botany, climatology, ecology, geochemistry, geography, geomorphology, geophysics, hydrology, paleontology, limnology, oceanography, palynology, physical anthropology, soil science, tectonophysics, and zoology.

The National Academy of Sciences is the adhering body to INQUA on behalf of the American scientists. The U.S. National Committee, under the chairmanship of Dr. R. S. Hoffmann, University of Kansas, plans U.S. participation in INQUA 
activities. One of the functions of the Committee is to arrange for travel support of U.S. scientists attending the international congresses of INQUA held at four-year intervals. Further information about the XIth Congress may be obtained by writing to Dr. Ismail P. Kartashov, Secretary-General XI INQUA Congress, Geological Institute, USSR Academy of Sciences, Pyzhevsky 7, Moscow 109017, USSR. 